\title{
THE EFFECT OF FOOD TEMPERATURE AND WAITING TIME ON DIETARY PROTEIN CONTENT IN FILTERED FOOD AT HOSPITAL
}

\author{
Dewi Mariyam Wijaya1,2), Eti Poncorini Pamungkasari3), \\ Ari Natalia Probandari3) \\ 1)Dr. Saiful Anwar Hospital, Malang, East Java \\ ${ }^{2)}$ Masters Program in Nutrition, Sebelas Maret University \\ 3)Department of Public Health, Faculty of Medicine, Sebelas Maret University
}

\begin{abstract}
Background: Filtered food is a food transition from solid to liquid. It is usually consumed by patients who have difficulty in chewing and take longer time to eat. The longer waiting time may affect the quality of food. The purpose of this study was to determine the effect of food temperature and waiting time on dietary protein content in filtered food at hospital.

Subjects and Method: This was a cross sectional study conducted at Dr. Saiful Anwar Hospital, Malang, East Java, from February to March 2017. A total of 60 filtered food samples prepare by hospital dietary unit were selected for this study. The dependent variable was protein content. The independent variables were food temperature and waiting time. Waiting time was measured by stopwatch from the time food is place in the container and time consumed by patients. Protein content was measured by Lowry method. Food temperature was measured by thermometer. Data were analyzed using multiple linear regression.
\end{abstract}

Results: Dietary protein content decreased with increasing food temperature $(b=-0.04 ; p=0.036)$ and longer waiting time $(b=-3.47 ; p=0.001)$.

Kesimpulan: Dietary protein content decreases with increasing food temperature and longer waiting time.

Keywords: dietary protein content, food temperature, waiting time, filtered food

Correspondence: Dewi Mariyam Wijaya. Dr. Saiful Anwar Hospital, Malang, East Java. Email: dewi.ronaa@gmail.com. Mobile: +6285259086110. 